\title{
RALB Gene
}

National Cancer Institute

\section{Source}

National Cancer Institute. RALB Gene. NCI Thesaurus. Code C18401.

This gene is involved in signal transduction and regulates receptor signaling. 